\title{
Electrocatalytic Oxidation of Methanol: Study with Pt:Mo Dispersed Catalysts
}

\author{
Almir Oliveira Neto, Joelma Perez, Wilhelmin T. Napporn, Edson A. Ticianelli and Ernesto R. Gonzalez* \\ Instituto de Química de São Carlos, Universidade de São Paulo, CP 780, 13560-970, São Carlos - SP, Brazil
}

\begin{abstract}
A oxidação eletroquímica do metanol foi estudada sobre ligas de Pt:Mo dispersa em carbono, preparadas utilizando um método recentemente desenvolvido neste laboratório. Análises de EDX confirmaram que a redução simultânea dos sais precursores de Pt e Mo conduzem a presença destes metais nas composições nominais inicialmente calculadas. A adição de Mo sobre Pt causa um aumento da corrente de oxidação, mas não produz um efeito catalítico para oxidação do metanol. A partir dos dados de polarização em várias concentrações de metanol foram obtidos diagramas de Tafel que apresentaram duas inclinações. A técnica de espectroscopia de massa diferencial aplicada "on line" a um experimento voltamétrico foi utilizada para investigar a distribuição de produtos e intermediários formados na oxidação de metanol.
\end{abstract}

The electrocatalytic oxidation of methanol on Pt:Mo dispersed on carbon prepared using an alternative method recently developed in this laboratory was investigated. The EDX analysis confirmed that the simultaneous reduction of the precursor salts of Pt and Mo leads to the presence of these materials at the nominal composition initially calculated. The addition of Mo to Pt causes an increase of the oxidation currents, but does not improve the catalytic effect for methanol oxidation. Tafel plots for various methanol concentrations showed the presence of two slopes. On line differential electrochemical mass spectrometry (DEMS) was used to investigate the distribution of products and intermediates in methanol oxidation.

Keywords: methanol electrooxidation, Pt:Mo dispersed catalysts

\section{Introduction}

The direct methanol fuel cell is an attractive alternative solution for electrochemical energy conversion applied to transportation. Liquid and gas feed systems have been proposed for this fuel cell operating with a solid polymer electrolyte membrane ${ }^{1}$. Most of the investigations made during the last years in this fuel cell are directed to the elucidation of the mechanism of the methanol oxidation, in order to find the best catalysts (low cost, good activity) for this reaction ${ }^{2}$.

Kinetic studies on Pt indicate the formation of poisoning intermediates, which can be only oxidized at high potentials. Many binary Pt based electrocatalysts have been proposed for this reaction: $\mathrm{Pt}: \mathrm{Ru}^{3-11}, \mathrm{Pt}: \mathrm{W}^{12}, \mathrm{Pt}: \mathrm{Sn}^{12}$, Pt:Mo12-14 and ternary systems $12,15-16$, and seem to give better results than Pt alone.

The present work presents a study the electroactivity of Pt:Mo dispersed catalysts towards the oxidation of methanol in acid medium. Various catalyst compositions were

Presented at the XI Simpósio Brasileiro de Eletroquímica e Eletroanalítica, Maragogi - AL, Brazil, April 5-9, 1999. Guest editor: Luis Alberto Avaca. elaborated and the activities investigated in the presence of different methanol concentrations. For the first time, dispersed catalysts on carbon have been investigated by means of differential electrochemical mass spectrometry (DEMS), with the aim to characterize the possible products and intermediates of the methanol oxidation reaction.

\section{Experimental}

The catalysts of Pt:Mo dispersed on carbon were obtained by simultaneous reduction of $\mathrm{Pt}$ and Mo compounds $\left(\mathrm{H}_{2} \mathrm{PtCl}_{6}\right.$ and $\left.(\mathrm{NH})_{4} \mathrm{Mo}_{7} \mathrm{O}_{24} \cdot 4 \mathrm{H}_{2} \mathrm{O}\right)$ by a method elaborated in this laboratory ${ }^{17}$. The atomic composition of the samples was confirmed by EDX. All the samples contained $20 \%$ in weight of catalyst dispersed on carbon and the nominal compositions were: 60:40, 70:30, 80:20, 90:10 and 100:0 of Pt:Mo.

The electrochemical characterization of the catalysts was performed using cyclic voltammetry and polarization techniques at room temperature. Thin porous coating electrodes (TPC) 18,19 employed in these studies were prepared by mixing the catalyst powders with a dilute suspension $(2 \% \mathrm{w} / \mathrm{w})$ of PTFE emulsion (DuPont TM30) and applied into the recess of a conventional rotating electrode. A conventional one compartment electro- 
chemical glass cell was used in the electrochemical experiments. A platinum foil served as the counter electrode and a reversible hydrogen as the reference electrode (RHE). All the experiments were carried out in $0.5 \mathrm{~mol} \mathrm{~L}^{-1} \mathrm{H}_{2} \mathrm{SO}_{4}$ solution (Merck). Methanol was Merck p.a. grade and water distilled and purified in a Milli-Q (Millipore) system. The electrolytes were saturated with purified $\mathrm{N}_{2}$ gas. All the experiments were conducted at room temperature $\left(25 \pm 1^{\circ} \mathrm{C}\right)$.

$\mathrm{X}$-ray diffraction (XRD) analyses were carried out with a X-URD, Carl Zeiss X-ray system.

For the DEMS measurements a computer controlled quadrupole mass spectrometer, MKS Instruments, was used. Details on this technique are given elsewhere $20-22$. The method allows the on-line detection of volatile and gaseous products of electrochemical reactions during the application of a potential scan. The electrochemical cell was constructed according to the principles described in Ref. 23. A reversible hydrogen and a platinum foil were used as reference and counter electrodes, respectively. The working electrode for the DEMS experiments was prepared by mixing the catalyst powders with a dilute suspension $(1 \% \mathrm{w} / \mathrm{w})$ of PTFE. This mixture was filtered and applied on a gold layer ( $1.13 \mathrm{~cm}^{2}$ area, $50 \mathrm{~nm}$ thickness) prepared by sputtering gold onto a SCIMAT ${ }^{\circledR}$ membrane (thickness $60 \mu \mathrm{m}$, mean pore size $0.17 \mu \mathrm{m}, 50 \%$ porosity).

\section{Results and Discussion}

After preparation, the dispersed Pt:Mo materials with various Pt:Mo ratios were characterised by EDX. These results are presented in Table 1. As seen in this Table, EDX analyses confirm the nominal composition of the samples. Figure 1 presents a comparison of the behaviour of the $\mathrm{X}$ ray diffraction patterns of all catalysts prepared in this work with commercial E-Tek 75:25 Pt:Mo samples. The results confirm that the samples prepared here present the same structure than the E-Tek material. The differences in the peak intensities are due to differences on the alloy concentrations (the E-Tek powder contains $30 \% \mathrm{Pt}: \mathrm{Mo} / \mathrm{C}$ and the samples prepared in this work $20 \% \mathrm{Pt}: \mathrm{Mo} / \mathrm{C}$ ).

Table 1. Composition analysis by EDX of the TPC Pt:Mo lectrodes.

\begin{tabular}{ccc}
\hline $\begin{array}{c}\text { Nominal composition } \\
\text { of the TPC Pt:Mo catalysts }\end{array}$ & $\begin{array}{c}\text { EDX } \\
\text { Pt content } \\
\text { Atom \% }\end{array}$ & $\begin{array}{c}\text { EDX } \\
\text { Mo content } \\
\text { Atom \% }\end{array}$ \\
\hline $90: 10$ & 86 & 14 \\
$80: 20$ & 77 & 23 \\
$70: 30$ & 67 & 33 \\
$60: 40$ & 63 & 37 \\
\hline
\end{tabular}

Figure 2 shows cyclic voltammograms in absence of methanol, recorded at $10 \mathrm{mV} \mathrm{s}^{-1}$ in $0.5 \mathrm{~mol} \mathrm{~L}^{-1} \mathrm{H}_{2} \mathrm{SO}_{4}$, for different thin porous coating Pt:Mo electrodes. The results show evidences of both $\mathrm{Pt}$ and Mo features, although the $\mathrm{Pt}-\mathrm{H}_{\text {upd }}$ region is not as well defined as on $\mathrm{Pt} / \mathrm{C}$ or $\mathrm{Pt}: \mathrm{Ru} / \mathrm{C}$ electrodes 19,24. Also, no evidences of the Pt-hydro-oxides features are seen. When the Mo contents increases from 10 to 40 atom percent, there is a progressive increase in the currents at potentials corresponding to the $\mathrm{Pt}-\mathrm{H}_{\text {upd }}$ and double layer regions of platinum. A redox process is also apparent at around $0.5 \mathrm{~V}$, with a current intensity that increases with the Mo content.

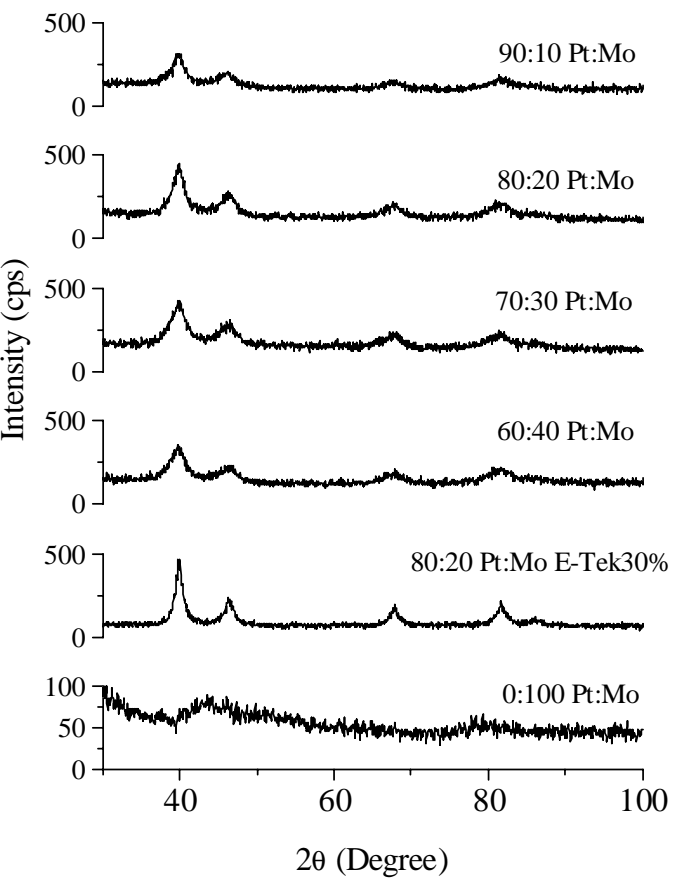

Figure 1. X-ray diffraction results for Pt:Mo catalysts. The compositions are indicated in the Figure.

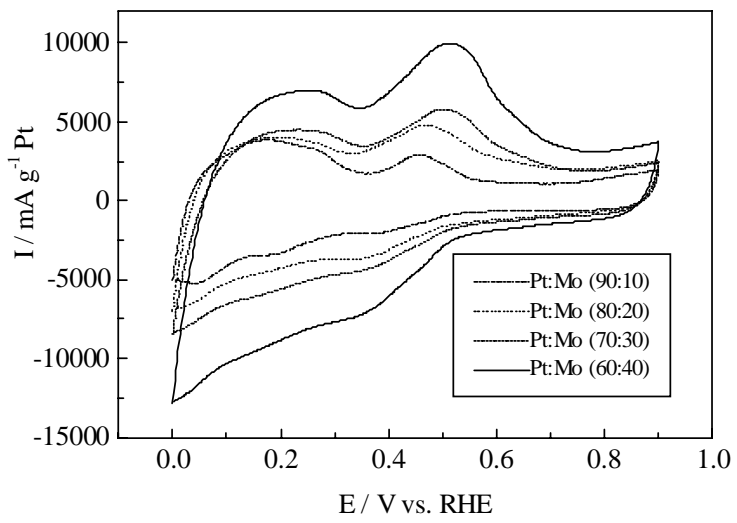

Figure 2. Cyclic voltammograms for the different Pt:Mo electrodes recorded in $0.5 \mathrm{~mol} \mathrm{~L}^{-1} \mathrm{H}_{2} \mathrm{SO}_{4}$ at $10 \mathrm{mV} \mathrm{s}^{-1}$. Currents were normalized with respect to the $\mathrm{Pt}$ loading.

The increase of current in the double layer region was observed previously with $\mathrm{Pt}$ :Ru catalysts 24 and various investigations have shown that it is due to the formation of 
adsorbed oxygenated species. This may also be the case for the Pt:Mo catalysts, for which X-ray absorption spectroscopy have indicated the presence of oxide layers for potentials as low as $0.1 \mathrm{~V}^{25}$. The presence of the redox process at about $0.5 \mathrm{~V}$ has been reported previously for other $\mathrm{Pt}: \mathrm{Mo}$ catalysts 25 and it is most likely due to a $\mathrm{Mo}^{4+} \leftrightarrow \mathrm{Mo}^{6+}$ oxidation state change of Mo.

Figure 3 presents cyclic voltammetric curves for methanol oxidation on the carbon supported Pt:Mo (70:30) catalyst. Comparing the curves for the different methanol concentrations, only small differences are observed in the potentials corresponding to the onset of the methanol oxidation reaction. Figure 4 illustrates the corresponding $\log (j)$ vs. E curves (Tafel diagrams) obtained from the cathodic scans of the cyclic voltammograms with the currents normalised with respect to the Pt loading. In this case, the results show a potential shift of ca. $25 \mathrm{mV}$ to more positive potentials for the methanol concentration of $1 \mathrm{~mol} \mathrm{~L}^{-1}$ in comparison with the concentration of $0.1 \mathrm{~mol} \mathrm{~L}^{-1}$, indicating a smaller catalytic effect at the higher concentration. In all cases the Tafel diagrams present two slopes: $\sim 35 \mathrm{mV} \mathrm{dec}^{-1}$ in the low current region and $\sim 240 \mathrm{mV} \mathrm{dec}^{-1}$ in the high current region.

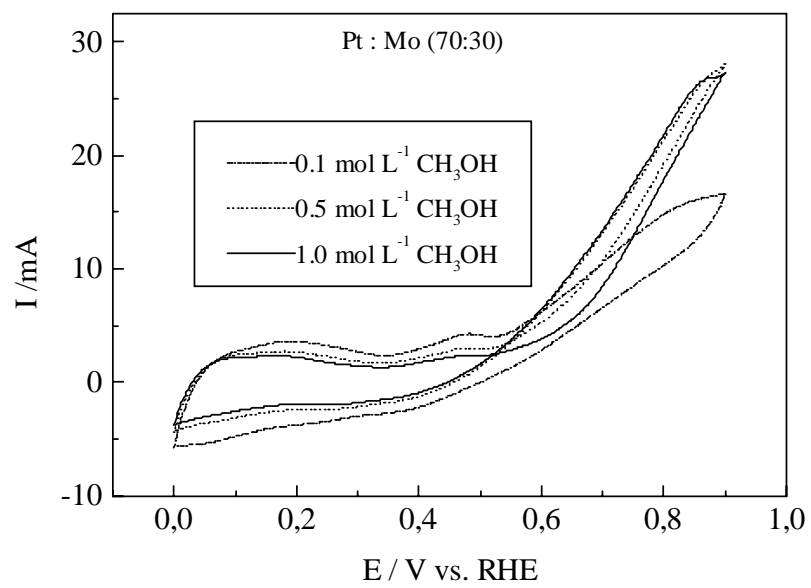

Figure 3. Cyclic voltammograms for Pt:Mo (70:30) recorded in $0.5 \mathrm{~mol} \mathrm{~L}^{-1} \mathrm{H}_{2} \mathrm{SO}_{4}$ at $10 \mathrm{mV} \mathrm{s}^{-1}$ in the presence of various methanol concentrations.

Cyclic voltammograms in the presence of $0.1 \mathrm{~mol} \mathrm{~L}^{-1}$ and $1.0 \mathrm{~mol} \mathrm{~L}^{-1} \mathrm{CH}_{3} \mathrm{OH}$ in $0.5 \mathrm{~mol} \mathrm{~L}^{-1} \mathrm{H}_{2} \mathrm{SO}_{4}$ for different Pt:Mo electrodes at $10 \mathrm{mV} \mathrm{s}^{-1}$ are presented in Figure 5. In both cases the currents were normalised with respect to the Pt loading in the electrode. In Figure 6, the results corresponding to the anodic scan for $0.1 \mathrm{~mol} \mathrm{~L}^{-1}$ methanol were re-plotted after subtraction of the background responses due to the Pt:Mo features in the supporting electrolyte (Figure 2).

In Figure 5, it is seen that the carbon supported 60: 40 Pt:Mo catalyst gives the higher current density for the oxidation processes in both methanol concentrations.

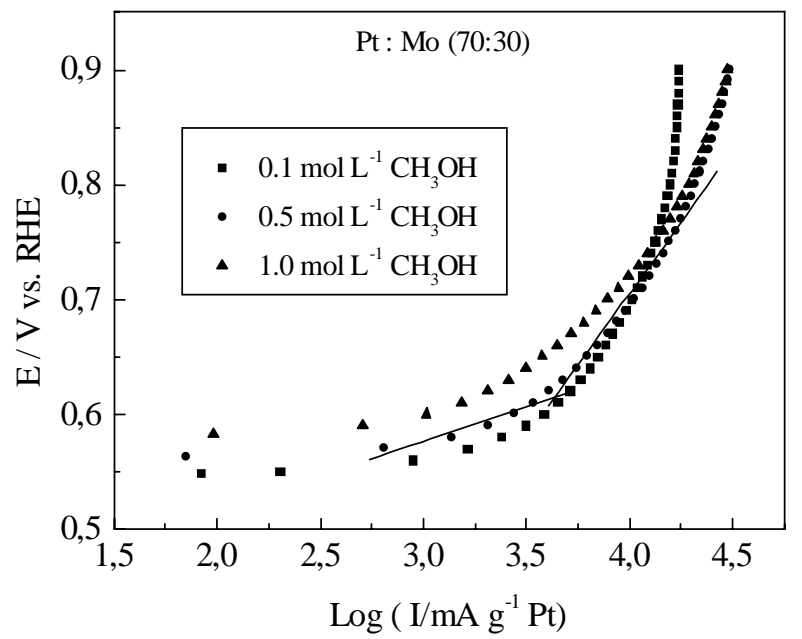

Figure 4. $\log (\mathrm{j})$ vs. E curves for the oxidation of methanol on Pt:Mo (70:30) catalysts in $0.5 \mathrm{~mol} \mathrm{~L}^{-1} \mathrm{H}_{2} \mathrm{SO}_{4}$. Currents were normalized with respect to the Pt loading.

However, after correction of background currents (Figure 6 ), it is observed that the onset of methanol oxidation starts at lower potentials for the catalyst with 90:10 Pt:Mo atomic ratio, demonstrating the higher catalytic activity of this material compared with the other compositions. Figure 6 also shows a comparison of the behaviour of the catalysts used in this work with that of a commercial ETek 75:25 Pt:Mo sample. These results clearly show that the commercial sample presents a lower catalytic effect than the catalysts prepared here with alternative method.

Figure 7 presents Tafel diagrams comparing the performance of the several Pt:Mo catalysts with that of pure Pt for methanol oxidation. For all Pt:Mo catalysts, much smaller currents were observed below $0.55 / 0.6 \mathrm{~V}$, when compared with the response of pure Pt. However, for more positive potentials, the activity of the Pt:Mo catalysts increases with the amount of Mo and the electrodes with 70:30 and 60:40 Pt:Mo present higher oxidation currents than those of the catalyst containing Pt alone. This behaviour indicates that the Pt:Mo catalysts are not much effective for the initiation of the methanol oxidation reaction. However, the increase of the oxidation currents at high potentials denotes a better tolerance to the poisoning species (mainly $\mathrm{CO}$ ) formed as intermediates in the oxidation of methanol. This observation is in agreement with the improvements in $\mathrm{CO}$ tolerance observed with $\mathrm{Pt}: \mathrm{Mo} / \mathrm{C}$ for the hydrogen oxidation reaction at $85^{\circ} \mathrm{C}$ with 100 ppm $\mathrm{CO}$ in the $\mathrm{H}_{2}$ gas, which show a two to three fold enhancement in performance compared to the current state of the art $\mathrm{Pt}: \mathrm{Ru} / \mathrm{C}$ anodes 26 .

As in the case of Figure 4, the results in Figure 7 show that for the Pt:Mo catalysts the Tafel plots present two slopes, that is, 30-35 $\mathrm{mV} \mathrm{dec}^{-1}$ at low current densities and 230-250 $\mathrm{mV} \mathrm{dec}-1$ at high current densities. It is interesting to com- 

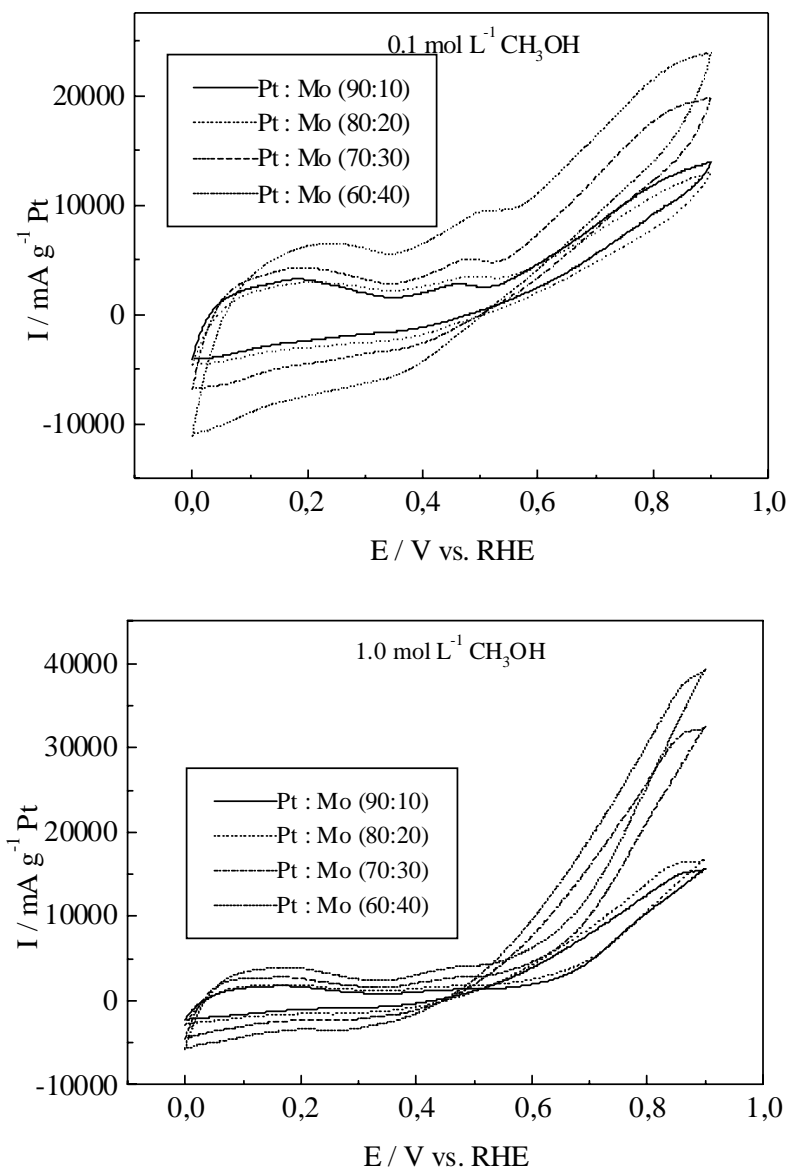

Figure 5. Cyclic voltammograms for the different Pt:Mo electrodes recorded in $0.5 \mathrm{~mol} \mathrm{~L}^{-1} \mathrm{H}_{2} \mathrm{SO}_{4}$ at $10 \mathrm{mV} \mathrm{s}^{-1}$ in the presence of $0.1 \mathrm{~mol} \mathrm{~L}^{-1} \mathrm{CH}_{3} \mathrm{OH}$ and $1.0 \mathrm{~mol} \mathrm{~L}^{-1} \mathrm{CH}_{3} \mathrm{OH}$. Currents were normalized with respect to the Pt loading.

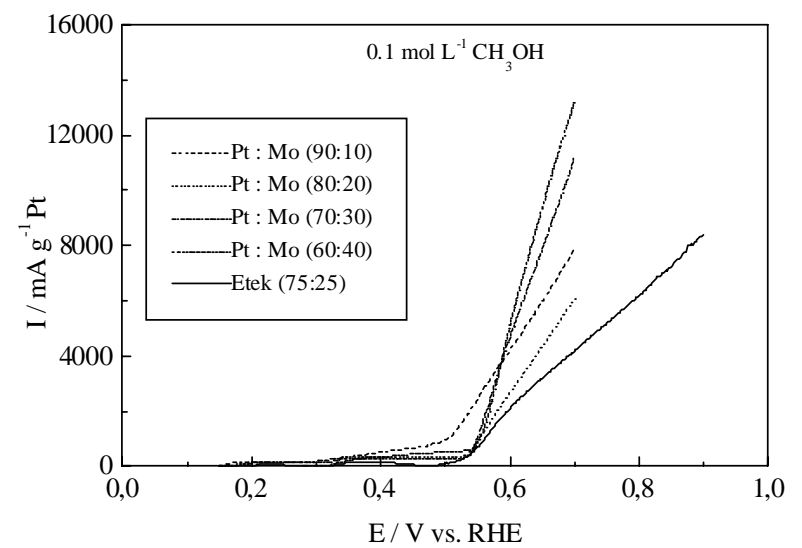

Figure 6. Comparison of current density vs. potential curves of the different TPC Pt:Mo electrodes and for a commercial E-Tek sample in $0.5 \mathrm{~mol} \mathrm{~L}^{-1} \mathrm{H}_{2} \mathrm{SO}_{4}$ in the presence of $0.1 \mathrm{~mol} \mathrm{~L}^{-1} \mathrm{CH}_{3} \mathrm{OH}$. Currents were corrected for the background response and normalized with respect to the Pt loading.

pare these data with those in pure Pt for which the slopes are 100 and $270 \mathrm{mV} \mathrm{dec}^{-1}$. The first value for this catalyst is the same as that reported in the literature ${ }^{26}$. The different values

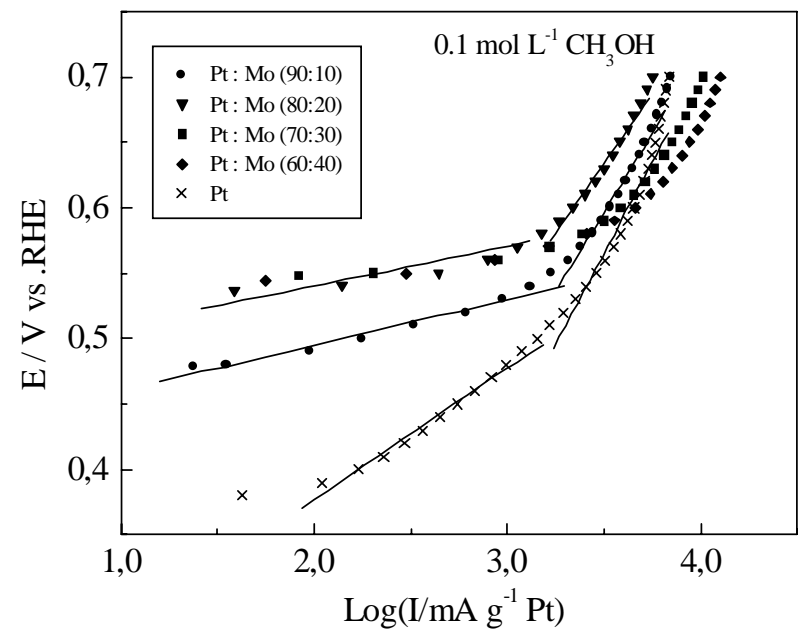

Figure 7. Comparison of Tafel plots for the different TPC electrodes: Pt:Mo and $\mathrm{Pt}$, in $0.5 \mathrm{~mol} \mathrm{~L}^{-1} \mathrm{H}_{2} \mathrm{SO}_{4}$ in the presence of $0.1 \mathrm{M} \mathrm{CH}_{3} \mathrm{OH}$.

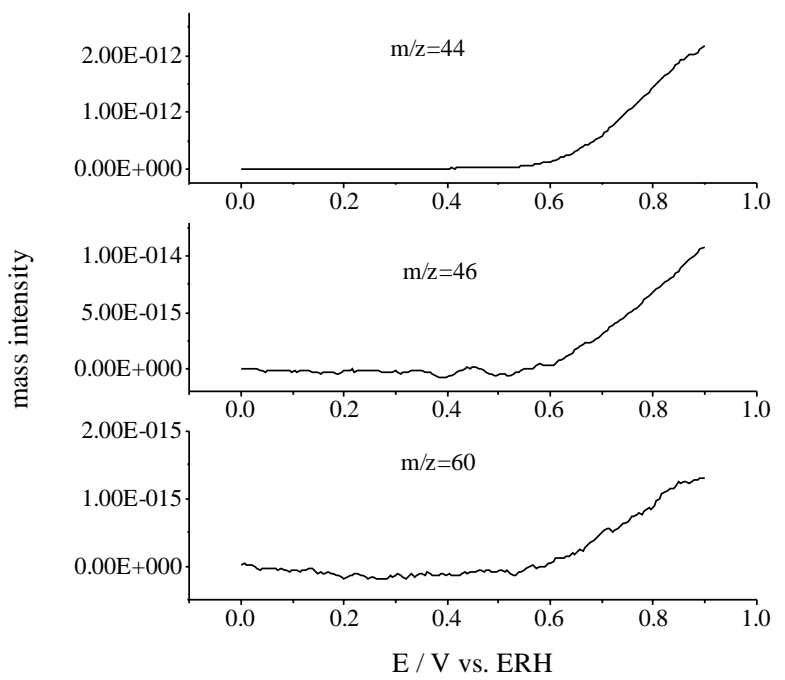

Figure 8. On-line mass signals vs. potential for the DEMS technique for the oxidation of methanol on Pt:Mo $(60: 40)$ catalysts in $0.5 \mathrm{~mol}$ $\mathrm{L}^{-1} \mathrm{H}_{2} \mathrm{SO}_{4}$ in the presence of $0.1 \mathrm{~mol} \mathrm{~L}^{-1} \mathrm{CH}_{3} \mathrm{OH}$ at $10 \mathrm{mV} \mathrm{s}^{-1}$ : (a) $\mathrm{m} / \mathrm{z}=44$; (b) $\mathrm{m} / \mathrm{z}=46$; (c) $\mathrm{m} / \mathrm{z}=60$.

of the first Tafel slope for the Pt and Pt:Mo catalysts can be related to effects of the particle size and distribution, because these have been shown to play important roles in the mechanism of oxidation of small organic molecules such as methanol, formic acid and carbon monoxide 27 . However, in the present case, it is more probable that the differences are related to the formation of oxygenated species at low potentials. The presence of these species is evident for Pt:Mo but they are completely absent for pure Pt.

Figure 8 presents the results of DEMS analysis for the oxidation of methanol in the 60:40 Pt:Mo catalyst. The mass signals $(\mathrm{m} / \mathrm{z})$ analysed were: $44\left(\mathrm{CO}_{2}\right), 46(\mathrm{HCOOH})$ and 60 $\left(\mathrm{HCOOCH}_{3}\right)$. It is seen that all mass signals start to increase at about $0.55 \mathrm{~V}$, corresponding to the same potential 
where the methanol oxidation starts to take place (Figs. 3 and $5)$. It is observed that the $\mathrm{m} / \mathrm{z}=44$ signal is considerable larger than the others, indicating that the most important product in the oxidation of methanol is $\mathrm{CO}_{2}$. This behaviour is consistent with the DEMS analysis of other non-dispersed catalysts 11,22 . Further studies of the oxidation of methanol are under way to compare the product distributions for $\mathrm{Pt}: \mathrm{Mo} / \mathrm{C}$ with those of other dispersed catalysts.

\section{Conclusion}

The experiments described in this work show that the alternative preparation method of the Pt:Mo catalysts leads to active materials. The addition of Mo to Pt causes a significant increase of the oxidation currents, but does not show a catalytic effect for the initiation of methanol oxidation.

The DEMS experiments, performed for the first time in this type of catalyst, show the formation of $\mathrm{CO}_{2}$, formic acid and methyl formate at potentials that coincide with the increase of the electrochemical oxidation currents.

\section{Acknowledgments}

The authors wish to thank Fundação de Amparo à Pesquisa do Estado de São Paulo (FAPESP, Proc 97/02471-6 and 95/ 0692-0), Conselho Nacional de Desenvolvimento Científico e Tecnológico (CNPq), Fundação Coordenação de Aperfeiçoamento de Pessoal de Nível Superior (CAPES) and Financiadora de Estudos e Projetos (FINEP), for financial supports.

\section{References}

1. Hogarth, M.; Christensen, P.; Hamnett, A.; Shukla, A. J. Power Sources 1997, 69, 113; ibid 1997, 69, 125.

2. Beden, B.; Lamy, C.; Leger, J. -M.Modern Aspects of Electrochemistry, Bockris, J. O'M.; Conway, B.E.; White, R.E.(Eds.), Vol. 22, Plenum, New York, 1992, p. 97.

3. Perez, J.; Tanaka, A. A.; Gonzalez, E. R.; Ticianelli, E. A. J. Electrochem. Soc. 1994, 141, 431.

4. Perez, J.; Gonzalez, E. R.; Ticianelli, E. A.Electrochim. Acta 1998,44, 1329.

5. Gasteiger, H.; Markovic, N. M.; Ross, P. N.;. Cairns, E. J. J. Electrochem. Soc. 1994, 141, 1796.

6. Kauranen, P. S.; Skou, E.; Munk, J. J. Electroanal. Chem. 1996, 404, 1.

7. Napporn, W. T.; Laborde, H.; Leger, J. -M.; Lamy, C. J. Electroanal Chem. 1996, 404, 153.
8. Kabbabi, A.; Faure, R.; Durand, R.; Beden, B.; Hahn, F.; Leger, J. -M.; Lamy, C. J. Electroanal Chem. 1998, $444,41$.

9. Pandya, K.; Anderson, E. B.; Sayers, D. E.; O'Grady, W. E. J. Phys. IV France 1997, 7, C2-995.

10. Chrzanowski, W.; Wieckowski, A. Langmuir 1998, 14, 1967.

11. Krausa, M.; Vielstich, W. J. Electroanal. Chem. 1994, 379, 307.

12. Gotz, M.; Went, H. Electrochim. Acta 1998,43, 3637.

13. Grgur, B. N.; Zhuang, G.; Markovic, N. M.; Ross, P. N. Phys. Chem. 1997, 101, 3910.

14. Grgur, B. N.; Markovic, N. M.; Ross Jr., P. N. Phys. Chem. 1998, 102, 2494.

15. Hamnett, A.; Kennedy, B. Electrochim. Acta, 1988, $33,1613$.

16. Liu, R.; Triantafillou, K.; Liu, L.; Pu, C.; Smith, C.; Smotkin, S.J. Electrochem. Soc. 1997, 44, 148.

17. Gonzalez,E. R.; Ticianelli,E. A.; Pinheiro, A.L. N.; Perez, J. Brazilian Patent I.N.P.I. - SP n 000321,1997 , Brazil.

18. Perez, J.; Tanaka, A. A.; Gonzalez, E. R.; Ticianelli, E. A. J. Electrochem. Soc. 1994, 141, 431.

19. Perez, J.; Gonzalez, E. R.; Ticianelli, E. A. Electrochim. Acta 1998, 44, 1329.

20. Wolter, O.; Heitbaum, J.; Ber. Bunsenges Phys. Chem. 1984, 88, 6.

21. Bittins-Cattaneo, B.; Cattaneo, E.; Königshoven, P.; Vielstich, W. Electroanalytical Chemistry - A Series of Advances, vol. 17, Ed. A. J. Bard, Marcel Dekker, Inc., New York, 1991, 181.

22. Iúdice de Souza, J. P.; Iwasita, T.; Nart, F. C.; Vielstich, W. J. Applied Electrochem. 1999, 30, 43.

23. Ianniello, R.; Schmidt, V. M.; Ber. Bunsenges Phys. Chem. 1995, 99, 83.

24. Oliveira Neto, A.; Perez, J.; Napporn, W. T.; Ticianelli, E. A.; Gonzalez, E. R. 194th Meeting of Electrochemical Society, Boston(USA) November 1998, Abstract no 1092.

25. Murkerjee, S.; Lee, S. J.; Ticianelli, E. A. Q.; McBreen, J.;Grgur, B. N.; Markovic, N.M.; Ross, P.N.; Giallombardop, J.R.; De Castro, E.S. Electrochem. and SolidState Letters 1999, 2, 12.

26. Gloaguen, F.; Napporn, W. T.; Croissant, M. -J.; Berthelot, S.; Leger, J. -M.; Lamy, C.; Srinivasan, S. $191^{\text {st }}$ meeting of Electrochem. Soc., Montreal (Canada) May 4-91997.

27. Gloaguen, F.; Léger, J. -M.; Lamy, C. J. Appl. Electrochem. 1997, 27, 1052.

Received: May 31, 1999

FAPESP helped in meeting the publication costs of this article. 